\title{
Grass weed management in transplanted eggplant'
}

\author{
Nelson Semiday," Luis Almodóvar' and Elvin Caraballo"
}

\begin{abstract}
Two field weed control experiments with transplanted eggplant (Solanum melongena L.) were conducted at the agricultural substation in Lajas in 1984-85 and one in Juana Díaz (1985). In Lajas (1984) a single postemergence application of either fluazifop-P (R)-2- $\{4-[5-$ (trifluoromethyl)-2-pyridinyl] oxy phenoxy $\}$ propanoic acid sethoxydim [2(1-ethoxyimino) butyl] -5-[2-(ethylthio) propyl-3 hydroxy-2-cyclohexen-1-one or quizalofop ( $\pm 2-\{4-[(6-c h l o r o-2-q u i n o x a l i n y l)$ oxy phenoxy] - propanoic acid \}ave excellent ( $90 \%$ or more) control of grasses for 10 weeks after transplanting eggplant. Eggplant yields increased substantially with manual cultivation after the herbicide applications. In a second experiment in Lajas in 1985 excellent 10-week control of grasses was provided by the combination of preemergence DCPA (dimethyl $2,3,5,6$ - tetrachloro-1, 4- benzenedicarboxylate) at $8.4 \mathrm{~kg}$ ai/ha followed by manual weedings, or the postemergence applications of either fluazifop-P $(0.28 \mathrm{~kg}$ ai $/ \mathrm{ha})$, sethoxydim $(0.27 \mathrm{~kg}$ ai $/ \mathrm{ha})$ or quizalofop $(0.28$ $\mathrm{kg} \mathrm{ai} / \mathrm{ha}) 2$ weeks after a hand weeding. The highest yield $(27,117 \mathrm{~kg} / \mathrm{ha})$ was obtained in plots with DCPA application plus 3 manual weedings.

In a similar experiment at Juana Díaz (1985) the combination of a manual weeding at 3 weeks plus the postemergence fluazifop-P application at 5 weeks was the only treatment that really controlled grasses during the first 10 weeks. Although the highest crop yield $(29,474 \mathrm{~kg} / \mathrm{ha})$ at Juana Díaz was obtained in plots with 3 manual weedings without herbicides, statistically comparable yields were obtained in plots with DCPA plus manual weedings at 3 and 5 weeks, with sethoxydim plus one weeding, and with fluazifop plus one weeding.
\end{abstract}

\section{RESUMEN}

Combate de malezas gramíneas en berenjena trasplantada

En las subestaciones experimentales de Lajas (1984 y 1985) y Juana Díaz (1985) se hicieron tres experimentos de campo con herbicidas en siembras de berenjena var. Rosita trasplantada. En el primer experimento en Lajas en 1984, una sola aplicación de los posemergentes fluazifop-P, setoxydim o quazilofop combatió excelentemente las malezas gramíneas en las primeras 10 semanas después del trasplante. El rendimiento aumentó substancialmente con cultivos manuales después de aplicar los herbicidas. En un segundo experimento en Lajas en 1985 con la aplicación de DCPA después del primer desyerbo o de fluazifop-P, sełoxydim o quazilofop, cada uno aplicado individualmente 2 semanas después de un cultivo manual, se logró un combate excelente de las malezas gramíneas durante 10 semanas. El mayor rendimiento de berenjenas $(27,117 \mathrm{~kg} . / \mathrm{ha}$.) se obtuvo en parcelas tratadas con DCPA más tres desyerbos manuales. 'Manuscript submitted to Editorial Board 14 September 1989.

${ }^{2}$ Assistant Researcher, Department of Crop Protection.

${ }^{3}$ Professor and Researcher, Department of Crop Protection.

${ }^{\lrcorner}$Research Assistant, Department of Horticulture. 


\begin{abstract}
Un tercer experimento en Juana Diaz en 1985 fue similar al realizado en Lajas el mismo año. En este experimento la combinación de un desyerbo manual a las 3 semanas con la aplicación de fluazifop-P a las 5 semanas fue el único tratamiento que reprimió excelentemente las malezas gramíneas durante 10 semanas. El mayor rendimiento de berenjenas $(29,474 \mathrm{~kg} . / \mathrm{ha}$.) en Lajas se obtuvo con tres desyerbos manuales. Cuando se combinó el DCPA con 2 ó 3 desyerbos manuales y setoxydim o fluazifop$P$ con desyerbo se obtuvieron rendimientos comparables.
\end{abstract}

\title{
INTRODUCTION
}

Eggplant (Solanum melongena L.) a minor vegetable crop, contributed $\$ 500,000$ to Puerto Rico's agricultural gross income in 1985-86 (4). Local eggplant production should be increased. More than 700 metric tons of fresh fruits were imported the same year from the Dominican Republic to satisfy local demand. Weed interference is a constraint to eggplant production; weeds compete with crops for essential nutrients and water, and also may cause allelopathic effects (2). DCPA is the only registered herbicide for weed control in eggplant (1). To control weeds, mechanical cultivation must be performed before applying DCPA in commercial plantings.

At the present time fluazifop-P, sethoxydim, quizalofop and other new chemicals are being evaluated in a wide variety of broadleaf crops $(7,8,9)$. These herbicides are selective for grass control with low herbicidal activity and persistence in the soil (5). Johnsongrass (Sorghum halepense L.) was controlled effectively in soybean reduced-tillage systems when fluazifop-P was applied (6). The present study was conducted to evaluate postemergence applications of fluazifop- $P$, sethoxydim and quizalofop in an effort to integrate the herbicides into the eggplant weedmanagement system where grass weeds are a problem.

\section{MATERIALS AND METHODS}

Three field experiments with transplanted eggplant cv. Rosita were established at Lajas (1984 and 1985) and Juana Díaz (1985) substations. The soil at Lajas is a Fraternidad clay (Vertic Udic Chromusterts, very fine montmorillonitic isohyperthermic, $25.5 \%$ sand, $21.9 \%$ silt, $53.9 \%$ clay, $3.0 \%$ organic matter and pH 6.5). At Juana Díaz the soil is a San Antón clay loam (Cumulic Haplustolls, fine-loamy, mixed, isohyperthermic, $\mathrm{pH} 7.3$ and $2.1 \%$ organic matter).

In the first experiment at Lajas, eggplant seedlings were transplanted 15 March 1984. Cultural and pest control practices recommended by the Agricultural Experiment Station were followed (3). Plots were $3.6 \mathrm{~m} \times 6.1 \mathrm{~m}$ with four rows $0.9 \mathrm{~m}$ apart and a planting distance of 0.5 $\mathrm{m}$ within the row. A complete randomized block design with four replications was used. Pendimethalin (N-(1-ethylpropyl)-3, 4-dimethyl-2,6-dinitrobenzeamine) at rates of 1.68 and $3.36 \mathrm{~kg}$ ai/ha was applied and incorporated into the soil the day before transplanting. Fluazifop-P $(0.28,0.56$ 
and $1.12 \mathrm{~kg}$ ai/ha), sethoxydim $(0.56,1.12$ and $2.24 \mathrm{~kg}$ ai/ha) and quizalofop ( 0.28 and $0.56 \mathrm{~kg}$ ai/ha) were sprayed on the crop and weeds after transplanting. After the initial weeding, all plots were split in half for cultivating two rows and leaving the other two rows unweeded. Yields from plots that were later treated with herbicides were compared to yields from plots receiving in addition three hand weedings at 3,7 and 11 weeks. Crop oil (20\% surfactant) at $0.5 \% \mathrm{v} / \mathrm{v}$ was added to fluazifop-P and Quizalofop and at $1 \% \mathrm{v} / \mathrm{v}$ to the sethoxydim treatments. For estimating commercial yield, eggplants were harvested in six pickings from 16 May to 9 July 1984.

On 26 February 1985 two experiments with $\mathrm{cv}$. Rosita were established at the same time at Juana Díaz and Lajas substations. The experiments were similar in plot size, planting methods, and experimental design in 1984. Eggplants were picked from 29 April to 20 June 1985. Fertilizer $10-10-8$ (N, P, K) at the rate of $746 \mathrm{~kg} / \mathrm{ha}$ per application was used three times: at planting, at blooming stage and after the second picking. Furrows were irrigated as needed at both localities.

\section{RESULTS AND DISCUSSION}

In 1984, a single application of either fluazifop-P, sethoxydim or quizalofop at three rates excellently controlled grasses for up to 10 weeks after transplanting eggplant (table 1), at which time no phytotoxicity to the crop was recorded. Eggplant yields in herbicide-treated plots were

TABLE 1,-Grass weed control at 5 and 10 weeks after transplanting eggplant in 1984

\begin{tabular}{|c|c|c|c|c|c|}
\hline \multirow[b]{2}{*}{ Treatment' } & \multirow{2}{*}{$\begin{array}{c}\text { Rate } \\
\mathrm{kg} \text { ai/ha }\end{array}$} & \multicolumn{2}{|c|}{$\begin{array}{c}\text { Number of grasses } \\
\text { in } 0.5 \mathrm{~m}^{2}\end{array}$} & \multicolumn{2}{|c|}{$\begin{array}{l}\text { Percent grass } \\
\text { control }\end{array}$} \\
\hline & & 5 weeks & 10 weeks & 5 weeks & 10 weeks \\
\hline Fluazifop-P & 0.28 & $3.0 \mathrm{~cd}^{3}$ & $0.7 \mathrm{~d}$ & 93 & 96 \\
\hline Fluazifop-P & 0.56 & $1.6 \mathrm{~cd}$ & $0.0 \mathrm{~d}$ & 96 & 100 \\
\hline Fluazifop-P & 1.12 & $0.2 \mathrm{~d}$ & $0.2 \mathrm{~d}$ & 99 & 99 \\
\hline Sethoxydim & 0.56 & $0.7 \mathrm{~cd}$ & $0.5 \mathrm{~d}$ & 98 & 97 \\
\hline Sethoxydim & 1.12 & $0.0 \mathrm{~d}$ & $0.0 \mathrm{~d}$ & 100 & 100 \\
\hline Sethoxydim & 2.24 & $0.5 \mathrm{~d}$ & $0.2 \mathrm{~d}$ & 99 & 99 \\
\hline Quizalofop & 0.28 & $0.0 \mathrm{~d}$ & $0.5 \mathrm{~d}$ & 100 & 97 \\
\hline Quizalofop & 0.56 & $0.0 \mathrm{~d}$ & 0.2 & 100 & 100 \\
\hline Pendimethalin & 1.68 & $10.4 \mathrm{~b}$ & $7.7 \mathrm{~b}$ & 75 & 51 \\
\hline Pendimethalin & 3.36 & 7.2 be & $4.0 \mathrm{c}$ & 83 & 75 \\
\hline Hand-weeded check & - & $10.4 b$ & $6.0 \mathrm{bc}$ & 73 & 61 \\
\hline Non-weeded check & - & $41.4 \mathrm{a}$ & $15.7 \mathrm{a}$ & 0 & 0 \\
\hline
\end{tabular}

'Herbicide treatments were applied postemergence 3 weeks after transplanting, except pendimethalin applied pre-transplant.

${ }^{2}$ Means followed by the same letter do not differ significantly at $P=0.05$ using Duncan's multiple range test.

${ }_{3}^{3 P r e d o m i n a n t ~ g r a s s ~ w e e d s ~ w e r e ~ J o h n s o n g r a s s, ~ j u n g l e r i c e, ~ c r a b g r a s s ~ a n d ~ g o o s e g r a s s . ~}$ 
TABLE 2.-Fruit yield of eggplant as affected by herbicides and manual weedings at Lajas in 1984

\begin{tabular}{lccc}
\hline & & \multicolumn{2}{c}{ Fruit yield (kg/ha) } \\
\cline { 4 - 4 } Rreatment & $\begin{array}{c}\text { Rate } \mathrm{kg} \\
\mathrm{ai} / \mathrm{ha}\end{array}$ & Non-weeded & Weeded \\
\hline Fluazifop-P & 0.28 & $3,704 \mathrm{bc}$ & $22,572 \mathrm{~b}$ \\
Fluazifop-P & 0.56 & $6,325 \mathrm{abc}$ & $27,293 \mathrm{ab}$ \\
Fluazifop-P & 1.12 & $6,789 \mathrm{abc}$ & $24,303 \mathrm{~b}$ \\
Sethoxydim & 0.56 & $6,980 \mathrm{abc}$ & $25,329 \mathrm{~b}$ \\
Sethoxydim & 1.12 & $5,905 \mathrm{abc}$ & $27,195 \mathrm{ab}$ \\
Sethoxydim & 2.24 & $3,433 \mathrm{bc}$ & $21,299 \mathrm{~b}$ \\
Quizalofop & 0.28 & $8,628 \mathrm{ab}$ & $29,543 \mathrm{ab}$ \\
Quizalofop & 0.56 & $8,040 \mathrm{ab}$ & $27,104 \mathrm{ab}$ \\
Pendimethalin & 1.68 & $6,483 \mathrm{abc}$ & $31,403 \mathrm{ab}$ \\
Pendimethalin & 3.36 & $9,848 \mathrm{a}$ & $21,096 \mathrm{~b}$ \\
Hand-weeding $4 \mathrm{X}$ & - & - & $42,382 \mathrm{a}$ \\
Hand-weeding $3 \mathrm{X}$ & - & $2,270 \mathrm{c}$ & $24,620 \mathrm{~b}$ \\
\hline
\end{tabular}

'All treatments were weeded by hoeing at 5,7 , and 11 weeks after transplanting, except check $4 \mathrm{X}$ that was also weeded at 3 weeks.

'Means followed by the same letter do not differ significantly at $\mathrm{P}=0.05$ using Duncan's multiple range test.

substantially increased with hand-weeding 5,7 , and 11 weeks after transplanting (table 2). In herbicide-treated plots without weeding, crop yields were drastically reduced. The highest eggplant yield (42,382 $\mathrm{kg} / \mathrm{ha})$ was obtained in check plots weeded four times at $3,5,7$, and 11 weeks. Plots weeded 3 times only, starting at 5 weeks, were significantly $(P=0.05)$ lower yielders $(24,620 \mathrm{~kg} / \mathrm{ha})$. Apparently, as reflected by increased yields, the first weeding performed at 3 weeks was essential for reducing: early weed interference. The yield obtained in the treatment weeded 4 times was nearly twice that of the treatment with 3 hand weedings. Results of this experiment suggest that herbicide applications alone did not significantly increase eggplant yields. Low yields may be attributed to early weed interference during the first 5 weeks in plots that were later treated with postemergence herbicides. The critical period of weed interference in eggplant occurred 4 weeks after transplanting. ${ }^{5}$

Predominant grass weeds at Lajas were Johnsongrass (Sorghum halepense L.), junglerice (Echinochloa colona L.) (Link) and goosegrass (Eleusine indica L.). At Juana Díaz the predominant grasses were junglerice and crabgrass (Digitaria sanguinalis L.).

Table 3 shows the different weed control treatments applied in 1985. All treatments excellently controlled grasses at Lajas after 10 weeks (table 4). At Juana Diaz only, the hand-weeding and fluazifop-P treatments controlled grasses excellently. Highest eggplant yields at Lajas

Dr. L. Almodóvar. Personal communication. 
TABLE 3.-Weed control treatments on transplanted eggplant at Lajas and Juona Diaz in 1985

\begin{tabular}{lccc}
\hline $\begin{array}{c}\text { Rate } \\
\mathrm{kg} \text { ai/ha }\end{array}$ & $\begin{array}{c}\text { Weeding dates } \\
\text { (weeks) }\end{array}$ & $\begin{array}{c}\text { Herbicide } \\
\text { applitwation (weeks) }\end{array}$ \\
\hline Weeded & - & $3,5,9$ & - \\
DCPA & 8.4 & $3,5,9$ & 3 \\
DCPA & 8.4 & 3,5 & 3 \\
DCPA & 8.4 & 4,5 & 4 \\
Sethoxydim & 0.27 & 3 & 5 \\
Fluazifop-P & 0.28 & 3 & 5 \\
Quizalofop & 0.28 & 3 & 5 \\
Non-weeded & - & 0 & - \\
\hline
\end{tabular}

were obtained with DCPA ( $8.4 \mathrm{~kg}$ a.i./ha) plus two and three hand weedings. At Juana Díaz the lower yielders were the non-weeded, quazilofop and DCPA (late weeding) treatments. With standard recommended herbicide DCPA treatment, significantly $(P=0.05)$ lower yields were obtained at both places. Two to 3 handweedings plus DCPA are more costly than single weeding plus one application of either sethoxydim or fluazifop-P. Eggplant yields at Juana Díaz with either sethoxydim or fluazifop treatments were comparable to the highest yields obtained in other treatments; these two herbicide treatments may cost farmers less.

TABLE 4.-Effect of weed control treatments on grasses and eggplant fruit yield at two sites in $1985^{\prime}$

\begin{tabular}{|c|c|c|c|c|c|}
\hline \multirow[b]{2}{*}{ Treatment } & \multirow{2}{*}{$\begin{array}{c}\text { Times } \\
\text { weeded }\end{array}$} & \multicolumn{2}{|c|}{$\begin{array}{c}\text { Weed control } \\
\%\end{array}$} & \multicolumn{2}{|c|}{$\begin{array}{l}\text { Fruit yield } \\
\text { (kg/ha) }\end{array}$} \\
\hline & & Lajas & Juana Diaz & Lajas & Juand Diaz \\
\hline Weeded & 3 & .95 & 90 & $25,146 \mathrm{ab}$ & 29,474 a \\
\hline $\mathrm{DCPA}^{3}$ & 3 & 96 & 78 & $27,117 a$ & $26,101 \mathrm{ab}$ \\
\hline $\mathrm{DCPA}^{4}$ & 2 & 95 & 85 & $24,162 a b$ & $24,515 a b$ \\
\hline DCPA & 1 & 93 & 72 & $18,742 b c$ & $20,816 \mathrm{~b}$ \\
\hline Sethoxydim & 1 & 91 & 74 & $14,961 \mathrm{c}$ & $24,069 a b$ \\
\hline Fluazifop-P & 1 & 91 & 91 & $16,628 \mathrm{bc}$ & $22,767 a b$ \\
\hline Quazilofop & 1 & 96 & 75 & $16,010 \mathrm{c}$ & $21,547 \mathrm{~b}$ \\
\hline Non-weeded & 0 & 0 & 0 & $1,252 d$ & $366 c$ \\
\hline
\end{tabular}

'Data taken 10 weeks after transplanting eggplant.

"Means followed by the same letter do not differ significantly at $\mathrm{P}=0.05$ using Duncan's multiple range test.

${ }^{3}$ First manual weeding performed 3 weeks after transplanting.

'First manual weeding performed 4 weeks after transplanting. 


\section{LITERATURE CITED}

1. Acín Diaz, N., H. O'Farrill-Nieves y R. Montalvo Zapata, 1984. Plaguicidas con permiso de uso en hortalizas en Puerto Rico. Plaguicidas al Día. 5 (2): 7-11.

2. Almodóvar-Vega, L., C. D. Guzmán Pérez and N. Semidy-Laracuente, 1988. Response of eggplant (Solanum melongena. L.) transplants to exudates from roots of seven weed species. J. Agric. Univ. P. R. 72: 495-97.

3. Commonwealth of Puerto Rico, 1986. Facts and figures on Puerto Rico's Agriculture, 1985/86. Dep. Agric Office of Agricultural Statistics, Santurce, Puerto Rico.

4. Kells, J. J., W. F. Meggitt and D. Penner, 1986. Activity of selective postemergence grass herbicides in soil. Weed Sci. 34: 62-5.

5. Langemeier, M. A. and W. W. Witt, 1986. Johnsongrass (Sorghum halepense) control in reduced-tillage systems. Weed Sci. 34: 751-55.

6. Nastas, P., R. Frans and M. McElelland, 1986. Economics and new alternatives in cotton (Gossypium hirsutum) weed management programs. Weed Sci. 34: 634-38.

7. Parker, W. B., L. Thompson and F. Michael Godley, 1985. Integrating sethoxydim into soybean (Glycine max) weed management systems. Weed Sci. 33: 100-08.

8. Parsells, A. J., M. M. Fawzi, J. S. Claus and J. C. Summers, 1984. Assare- A new postemergence grass herbicide for use in soybeans, cotton and other broadleaf crops. Abstr. 1984 Meeting WSSA. p. 17-18. 